\title{
Short communication: Field study to investigate the associations between herd-level risk factors for milk fat depression and bulk tank milk fat percent in dairy herds feeding monensin
}

\author{
M. M. McCarthy, ${ }^{*}$ T. R. Overton, † G. D. Mechor, ${ }^{*}$ D. E. Bauman,† T. C. Jenkins, $\ddagger$ and D. V. Nydam $\S^{1}$ \\ *Elanco Animal Health, Greenfield, IN 46140 \\ †Department of Animal Science, Cornell University, Ithaca, NY 14853 \\ ‡Department of Animal and Veterinary Sciences, Clemson University, Clemson, SC 29634 \\ $\S$ Department of Population Medicine and Diagnostic Sciences, Cornell University, Ithaca, NY 14853
}

\begin{abstract}
Fat is the most variable milk component, and maintaining milk fat continues to be a challenge on commercial dairy farms. Our objectives were to establish associations between herd-level risk factors for milk fat depression and bulk tank milk fat content in commercial dairy herds feeding monensin. Seventy-nine Holstein commercial dairy herds in the northeast and Upper Midwest United States were enrolled in an observational study. Data were collected on herd characteristics, total mixed ration (TMR) samples, all component silage samples, and bulk tank milk samples. The unconditional univariable association of each explanatory variable and bulk tank milk fat percentage was evaluated using simple linear regression and multivariable regression models. Milk fat content of trans-10 C18:1 had an exponentially negative relationship to herd milk fat percentage. In general, milk fat content of fatty acids synthesized de novo in the mammary gland were positively related to herd milk fat, and the content of several trans-C18:1 fatty acids, which would be products of alternate pathways of ruminal biohydrogenation, were negatively related to herd milk fat. Variables related to TMR composition did not have univariable relationships with herd milk fat percentage. Herds that had $>49.8 \%$ of the TMR particles on the middle screen of the Penn State particle separator had higher milk fat percentage than those with $\leq 49.8 \%$, and herds with $>54.0 \%$ of TMR particles in the bottom pan had lower milk fat percentage than herds with $\leq 54.0 \%$. Dietary content of monounsaturated fatty acids (C16:1 and C18:1) had negative relationships with herd milk fat percentage; however, no single diet component accounted for more than $11 \%$ of the variation in herdlevel milk fat percentage. Univariable monensin dose
\end{abstract}

Received October 3, 2017.

Accepted December 27, 2017.

${ }^{1}$ Corresponding author: dvn2@cornell.edu was not associated with herd milk fat percentage. The relative lack of significant univariate relationships with herd-level milk fat suggests many factors contribute to milk fat content, and herds experiencing low milk fat will need to examine many potential risk factors when working to troubleshoot this challenge.

Key words: milk fat depression, monensin, unsaturated fatty acids

\section{Short Communication}

Classically, milk fat depression (MFD) is represented by a reduction in milk fat content and yield attributed to a shift in the biohydrogenation of C18 UFA and increased production of unique biohydrogenation intermediates (Bauman and Griinari, 2001; Bauman et al., 2011). In controlled experiments, the concentration of trans-10 C18:1 in milk fat has been shown to be a good marker for the shift in biohydrogenation (Lock et al., 2007; Rico and Harvatine, 2013). Previous work has demonstrated that trans-10,cis-12 CLA has an important role in modulating milk fat synthesis (Baumgard et al., 2000); however, only a portion of MFD is accounted for by this isomer, suggesting that other isomers and additional factors must also influence milk fat synthesis (Palmquist et al., 1993; Bauman et al., 2006).

It is well accepted that the presence of PUFA is a prerequisite for MFD (Bauman and Griinari, 2003), although many dietary factors may interact to induce this effect, including feed particle size (Grant et al., 1990a, b), NDF level (Griinari et al., 1998; Duffield et al., 2003; Rico and Harvatine, 2013), and the rate or extent of starch degradation (Oba and Allen, 2003; Lascano et al., 2016). Cows fed diets high in corn silage tend to have lower milk fat content than those fed diets containing other forage sources (Onetti et al., 2004; Wattiaux and Karg, 2004), but forage type is not always a predisposing factor for MFD (Dhiman and Satter, 1997; Groff and $\mathrm{Wu}, 2005)$. Further, supplementing lactating cattle with the ionophore monensin (Rumensin, Elanco Ani- 
mal Health, Greenfield, IN) has been associated with decreases in milk fat percentage (Duffield et al., 2008) and changes in ruminal VFA production (Ramanzin et al., 1997) or production of biohydrogenation intermediates (Bell et al., 2006) consistent with classical MFD. A recent study observed that up to $90 \%$ of herds in the northeastern United States fed monensin (Lawton et al., 2016). In our experience, when herds are having challenges with MFD, monensin is often removed from the diet, albeit with varying results on correcting the MFD. We are often asked if any preeminent factors contribute to MFD when troubleshooting challenges on commercial dairy herds. Based upon this, it was of interest to conduct a comprehensive field study of the factors that affect milk fat percentage. The objectives of our study were to investigate putative risk factors, with a specific interest in univariable factors that might be major contributors to herd-level milk fat variations in commercial dairy herds feeding monensin and to evaluate the fatty acid (FA) profile of bulk tank milk samples for the presence of FA intermediates consistent with the biohydrogenation theory of MFD.

Seventy-nine Holstein herds from the northeast and Upper Midwest United States were enrolled in a crosssectional observational study to investigate herd-level factors that affect milk fat percentage in herds feeding monensin. Herds were identified and enrolled by working in collaboration with allied industry herd service providers. The final data set consisted of 79 Holstein herds contributed by 48 different allied industry professionals from 28 organizations. The 48 individuals could be further categorized into feed company-based nutritionists $(\mathrm{n}=35)$, consulting group nutritionists (n $=8)$, and veterinarians $(\mathrm{n}=5)$. Herds from 10 states were included in the final data set. These included New York $(\mathrm{n}=43)$, Michigan $(\mathrm{n}=14)$, Pennsylvania $(\mathrm{n}=$ 9), Ohio $(\mathrm{n}=6)$, Maryland $(\mathrm{n}=2)$, New Hampshire (n $=1)$, Wisconsin $(\mathrm{n}=1)$, Maine $(\mathrm{n}=1)$, Minnesota ( $\mathrm{n}$ $=1)$, and Virginia $(\mathrm{n}=1)$. When enrolling herds, we sought to include a diverse sampling of herds, including some that were experiencing MFD during study sample collection. Data were collected during 1 visit to the herd by Cornell research staff and herd service providers, and consisted of a survey on herd and facility/ group characteristics, 3 duplicate samples of the highmilk production lactating cow group TMR, samples of all the component silages, and duplicate bulk tank milk samples (samples taken from 1 morning milking, tank agitated for $10 \mathrm{~min}$ before sample collections). We chose to sample the high-producing lactating cow group because these cows are at the highest risk of MFD on the dairy, and we hypothesized that their group characteristics would have the greatest relationship to herd- level milk fat. In addition to the survey and sample collection, copies of diet formulations that corresponded to the TMR samples were collected for all herds.

Milk samples were sent to a commercial laboratory for analysis of milk fat content (Dairy One, Ithaca, NY) using midinfrared analysis (AOAC International, 2000; method 972.160). The TMR samples were dried $\left(55^{\circ} \mathrm{C}\right)$ and ground (2-mm sieve) by Cumberland Valley Analytical Services (Maugansville, MD) for analysis of DM (Goering and Van Soest, 1970; AOAC International, 2000, method 930.15), CP (AOAC International, 2000, method 990.03), soluble CP (Krishnamoorthy et al., 1982), ADF (AOAC International, 2000, method 973.18), NDF (Van Soest et al., 1991), crude fat by ether extract (AOAC International, 2000, method 2003.05) and acid hydrolysis (AOAC International, 2000, method 954.02), ash (AOAC International, 2000, method 942.05), starch (Hall, 2009), and sugar (Dubois et al., 1956) using wet chemistry methods. The particle size of the TMR was assessed by Cumberland Valley Analytical Services using the Penn State particle separator (PSPS; Nasco, Fort Atkinson, WI) according to Lammers et al. (1996). A representative portion of the dried and ground sample was sent to Clemson University for analysis of FA composition by GLC (Sukhija and Palmquist, 1988; T. C. Jenkins Laboratory, Clemson University). Milk FAME were extracted from the bulk tank milk samples and methylated according to the procedure described by Bernal-Santos et al. (2003) and quantified by GLC and conditions reported by Perfield et al. (2002; D. E. Bauman Laboratory, Cornell University).

All statistical analyses were performed using SAS software (version 9.2; SAS Institute Inc., Cary, NC). The unconditional univariable association of each continuous explanatory variable and milk fat percentage was evaluated using simple linear regression with PROC Reg. The unconditional univariable association of each categorical explanatory variable and milk fat percentage was evaluated using a 2 -sample $t$-test with PROC Ttest. Similarly, each of the explanatory variables were offered to a multivariable general linear model with PROC GLM and PROC Mixed, where herd was a random effect among the fixed effects of interest in a mixed model. An ANOVA was used to study the relationship between bulk tank milk fat percentage and conditional relationships of the putative risk factors. Plausible 2-way interactions were evaluated. Backward, step-wise, and manual elimination of variables was used to select the most parsimonious model that explained the most variation in bulk tank milk fat percent, had all individual terms with a type 1 error risk of less than $5 \%$, and had the best model fit. All potential 
explanatory variables that were not potential biological confounders from cow and facility factor, as well as nutrient content submodels that had $P$-values $<0.2$, were offered to the model, uniting them to explore their conditional relationship to herd milk fat percentage. This was done, as described above, using a general linear model approach with herd as a random effect and manual backward stepwise removal of variables.

In our study sample, the mean and median (range) herd size was 474 and 370 cows $(30-2,800)$, herd milk fat percentage was 3.43 and 3.45 (2.70-4.30), and monensin dose was 258 and $250 \mathrm{mg} / \mathrm{d}(150-410)$. Descriptive statistics for milk FA profile of bulk tank samples are presented in Table 1. In the current study, we observed generally positive relationships of de novo-synthesized short-chain FA with herd milk fat percentage $(P=$ $0.002 ; \mathrm{R}^{2}=0.12$ ), consistent with the previous observations (Barbano et al., 2014; Woolpert et al., 2016, 2017). We also noted a generally negative relationship of trans C18:1 isomers that are produced by other alternate pathways of ruminal biohydrogenation with herd milk fat percentage. Similar to observations of Woolpert et al. $(2016,2017)$, we observed lower preformed FA in herds with higher bulk tank milk fat in the current data set $\left(P=0.04 ; \mathrm{R}^{2}=0.10\right)$, and with the recent advances in mid-infrared methodology (Barbano et al., 2014) the reporting of bulk tank FA data may be a useful diagnostic test for the investigation of MFD. The coordinated changes in milk FA composition are consistent with alterations in FA synthesis by specific FA isomers, as demonstrated in controlled experiments (Palmquist et al., 1993; Bauman and Griinari, 2003). Previous work (Hinrichsen et al., 2006; Kadegowda et al., 2008) using data from controlled feeding and infusion experiments determined that a strong relationship existed between the milk fat content of trans-10 C18:1 and milk fat percentage, such that this marker of altered biohydrogenation in the rumen increased as milk fat percentage decreased. Results represented in Figure 1 suggest that the same negative, curvilinear relationship existed in the present study for commercial dairy herds fed monensin. This suggests that low milk fat

Table 1. Descriptive statistics for bulk tank sample milk fatty acid profiles ${ }^{1}$

\begin{tabular}{|c|c|c|c|c|c|c|c|}
\hline Variable & $\mathrm{n}^{2}$ & Mean & $\mathrm{SD}$ & $\begin{array}{c}25 \mathrm{th} \\
\text { percentile }\end{array}$ & Median & $\begin{array}{c}\text { 75th } \\
\text { percentile }\end{array}$ & Range \\
\hline $\mathrm{C} 4: 0$ & 77 & 3.76 & 0.67 & 3.52 & 3.75 & 4.00 & $1.99-7.92$ \\
\hline C6:0 & 77 & 1.97 & 0.28 & 1.89 & 2.01 & 2.13 & $0.32-2.40$ \\
\hline C8:0 & 77 & 1.10 & 0.13 & 1.02 & 1.11 & 1.18 & $0.72-1.35$ \\
\hline C10:0 & 77 & 2.44 & 0.32 & 2.23 & 2.45 & 2.63 & $1.60-3.06$ \\
\hline $\mathrm{C} 12: 0$ & 77 & 2.77 & 0.34 & 2.55 & 2.75 & 2.98 & $2.00-3.51$ \\
\hline C14:0 & 77 & 9.58 & 0.71 & 8.95 & 9.53 & 10.02 & $7.87-11.16$ \\
\hline C14:1 & 77 & 0.91 & 0.21 & 0.78 & 0.88 & 0.98 & $0.63-2.09$ \\
\hline C15:0 & 77 & 0.87 & 0.10 & 0.82 & 0.86 & 0.92 & $0.71-1.28$ \\
\hline $\mathrm{C} 16: 0$ & 77 & 27.94 & 1.52 & 26.95 & 27.86 & 28.96 & $25.09-32.15$ \\
\hline C16:1 & 77 & 1.61 & 0.44 & 1.46 & 1.55 & 1.74 & $0.20-4.56$ \\
\hline C17:0 & 77 & 0.53 & 0.11 & 0.48 & 0.53 & 0.57 & $0.37-1.30$ \\
\hline C18:0 & 77 & 10.77 & 1.08 & 10.04 & 10.80 & 11.52 & $8.36-13.24$ \\
\hline C18:1 trans-4 & 77 & 0.032 & 0.020 & 0.023 & 0.030 & 0.037 & $0-0.134$ \\
\hline C18:1 trans-5 & 77 & 0.028 & 0.028 & 0.018 & 0.022 & 0.030 & $0-0.170$ \\
\hline C18:1 trans $-6-8$ & 77 & 0.432 & 0.123 & 0.358 & 0.412 & 0.467 & $0.270-0.841$ \\
\hline C18:1 trans-9 & 77 & 0.343 & 0.074 & 0.300 & 0.330 & 0.384 & $0.214-0.586$ \\
\hline C18:1 trans-10 & 77 & 1.060 & 0.814 & 0.583 & 0.750 & 1.167 & $0.370-4.911$ \\
\hline C18:1 trans-11 & 77 & 1.441 & 0.444 & 1.182 & 1.405 & 1.630 & $0.936-4.440$ \\
\hline C18:1 trans -12 & 77 & 0.661 & 0.156 & 0.590 & 0.680 & 0.756 & $0-0.901$ \\
\hline $\mathrm{C} 18: 1$ cis-9 & 77 & 24.53 & 1.62 & 23.57 & 24.51 & 25.47 & $20.48-28.82$ \\
\hline C18:2 cis-9,cis-12 & 76 & 3.08 & 0.62 & 2.65 & 3.14 & 3.51 & $0.94-4.43$ \\
\hline C20:0 & 77 & 0.097 & 0.047 & 0.080 & 0.090 & 0.100 & $0.017-0.332$ \\
\hline C18:3 & 77 & 0.426 & 0.116 & 0.350 & 0.430 & 0.502 & $0.160-0.751$ \\
\hline CLA cis-9,trans-11 & 77 & 0.558 & 0.162 & 0.474 & 0.556 & 0.651 & $0-0.946$ \\
\hline CLA trans-10, cis-12 & 77 & 0.020 & 0.016 & 0 & 0.024 & 0.030 & $0-0.096$ \\
\hline Unknown & 77 & 3.07 & 0.67 & 2.81 & 2.98 & 3.09 & $1.82-6.76$ \\
\hline Ratio $^{3}$ & 77 & 0.78 & 0.72 & 0.49 & 0.56 & 0.71 & $0.23-4.84$ \\
\hline Ratio alternate $^{4}$ & 77 & 0.58 & 0.57 & 0.35 & 0.41 & 0.52 & $0.17-4.53$ \\
\hline Total $<\mathrm{C} 16$ & 77 & 22.5 & 1.8 & 22.2 & 22.3 & 24.5 & $17.8-26.1$ \\
\hline Total C16 & 77 & 29.5 & 1.6 & 28.3 & 29.5 & 30.9 & $26.6-34.0$ \\
\hline Total $>\mathrm{C} 16$ & 77 & 43.4 & 2.8 & 42.2 & 43.6 & 45.7 & $35.8-49.4$ \\
\hline
\end{tabular}

${ }^{1}$ All values are expressed as $\mathrm{g} / 100 \mathrm{~g}$ of fatty acids.

${ }^{2}$ Number of herds sampled.

${ }^{3}$ Ratio of C18:1 trans-10:C18:1 trans-11.

${ }^{4}$ Ratio of the sum of C18:1 trans-10 and CLA trans-10, cis-12 to the sum of C18:1 trans-11 and CLA cis-9,trans-11. 




Figure 1. Relationship of trans-10 C18:1 fatty acid (FA) content of bulk tank milk fat and milk fat percentage across 79 northeast and Upper Midwest dairy herds feeding monensin.

percentage at the herd level is associated with changes in biohydrogenation pathways.

The descriptive statistics for nutrient content and particle size on the TMR samples are presented in Table 2. The mean and median values for nutrient content and distribution of TMR particles are comparable to each other in most cases, and in our opinion they are consistent with values commonly seen in diets in the northeast and Upper Midwest. Furthermore, the nutrient content and distribution of TMR particles have standard deviations and ranges that also appear to reflect the population of diets fed in the northeast and Upper Midwest. Within this population and ranges of values represented by herds in this data set, we found no significant univariable relationships of dietary variables with herd milk fat percentage (data not shown). In contrast to wet chemistry results, univariable relationships did exist between aspects of particle size and herd milk fat percentage. Although there was not an important relationship of the proportion of TMR particles on the top screen of the PSPS with herd milk fat percentage $\left(P=0.35, \mathrm{R}^{2}=0.01\right)$, we noted inverse relationships of the proportion of particles on the bottom pan and middle screen. Decreasing herd milk fat percentage was associated with increasing proportions of TMR particles on the bottom pan $\left(P=0.003, \mathrm{R}^{2}=\right.$ 0.11 ; Figure 2A) and decreasing proportions of TMR particles on the middle screen $\left(P=0.008, \mathrm{R}^{2}=0.09\right.$; Figure 2B); however, these differences each accounted for $\leq 11 \%$ of the overall variation in herd milk fat percentage. Grant et al. (1990a,b) observed that cows fed diets containing fine ground alfalfa silage and hay had decreased milk fat percentages compared with cows fed a coarse ground alfalfa silage and hay, indicating that reduced particle size likely altered ruminal fermentation and retention time of particles in the rumen.

We used univariable analysis, categorizing factors using the third quartile as a cut-point, to investigate the possibility of a threshold effect of a predictor variable on herd milk fat percentage that may have been obscured by linear regression approaches. The $P$-values and differences generated using this approach reflect the comparison of the top $25 \%$ of herds for a given variable with the bottom $75 \%$ of herds for the same variable. Consistent with the lack of relationship of most of these variables with milk fat when analyzed as continuous variables, we found no relationship of herd milk fat with monensin dose, carbohydrate variables, and total dietary fat variables (data not shown). Similar to the significant relationships with herd milk fat percentage when analyzed as continuous variables, herds with $>49.8 \%$ of the TMR particles on the middle screen of the PSPS had increased milk fat (3.54\%) compared with those with $\leq 49.8 \%(3.37 \% ; P=0.02)$, and herds with $>54.0 \%$ of TMR particles in the bottom pan of the PSPS had lower milk fat percentage (3.26) than herds with $\leq 54.0 \%$ of TMR particles in the bottom pan $(3.49 \% ; P<0.001)$.

When a multivariable regression was performed and all measured TMR variables and herd management factors were included in the model, followed by a stepwise, backward elimination of variables, the factors remaining in the model were categorical TMR DM $(P$ $=0.008 ;>50$ or $<50 \%$ ) and categorical percentage of 
Table 2. Descriptive statistics for TMR components and dietary factors across 79 northeast and Upper Midwest dairy herds feeding monensin ${ }^{1}$

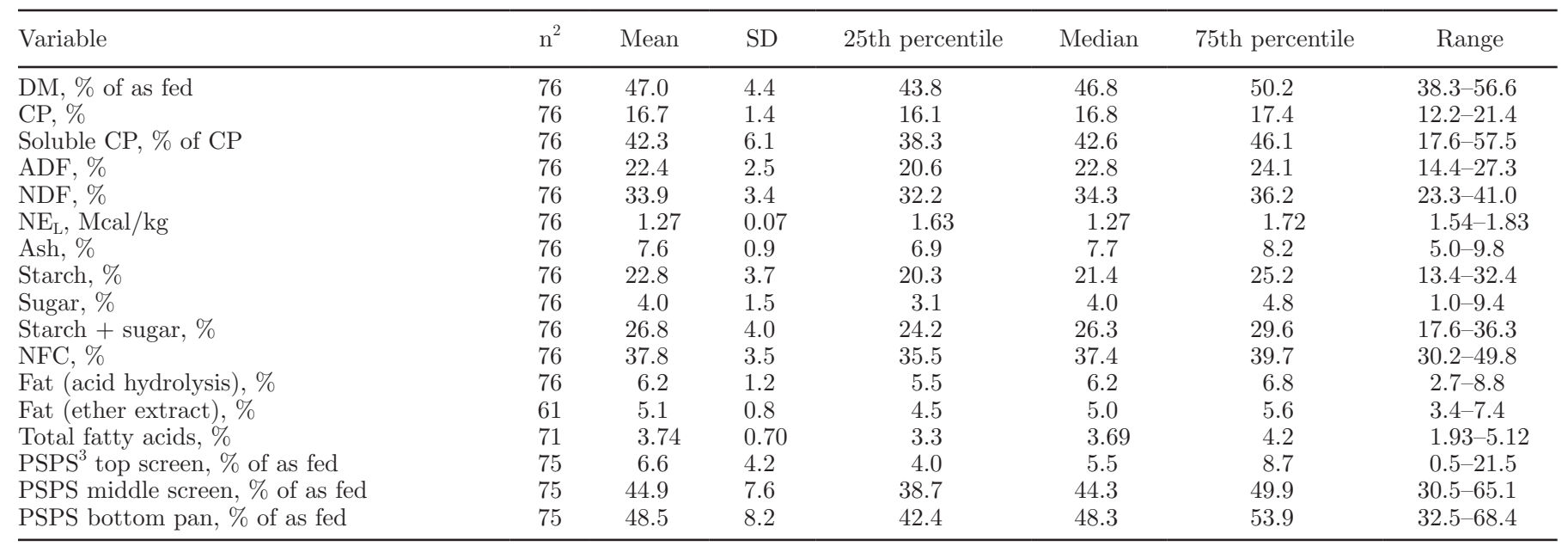

${ }^{1}$ Except as noted, all values are expressed on a DM basis.

${ }^{2}$ Number of herds sampled.

${ }^{3}$ Penn State particle separator (Nasco, Fort Atkinson, WI).

particles on the bottom pan of the PSPS $(P=0.0003$; $>54$ or $<54 \%$ ). Together TMR DM and bottom pan particles accounted for $21 \%$ of the variation in herd milk fat percentage.

Most of the relationships of individual TMR FA with herd milk fat percentage were not significant (data not shown); however, diet content of the MUFA C16:1 and C18:1 tended to have negative relationships with herd milk fat percentage $\left(P=0.007, \mathrm{R}^{2}=0.10 ; P=0.07, \mathrm{R}^{2}\right.$ $=0.05$ ). Interestingly content and intake of $\mathrm{C} 18: 2$, the precursor for known FA isomers that decrease milk fat percentage, was not related to herd milk fat percentage in our study population $(P=0.83)$; however, the relationship with C18:1 intake is of interest. In controlled research studies, the effect of C18:1 on MFD has been variable (Selner and Schultz, 1980; Jenkins 1998; Rego et al., 2009), and He et al. (2012) observed a negative linear relationship between a high C18:1 diet and milk fat; in our study, however, C18:2 had a stronger negative relationship with milk fat. Based upon pathways of biohydrogenation and known FA isomers that decrease milk fat synthesis in the mammary gland, one would speculate that higher intakes of C18:1 may decrease milk fat indirectly by interacting with biohydrogenation pathways to increase passage of biohydrogenation intermediates at higher levels.

Because of the antimicrobial nature of ionophores in the rumen and the alteration in VFA production (Ramanzin et al., 1997), it is reasonable to expect that monensin functions according to the biohydrogenation theory and causes a microbial shift in the rumen environment that alters pathways of biohydrogenation (Bell et al., 2006). The meta-analysis of Duffield et al. (2008) revealed a negative effect of monensin on milk fat percentage, although those authors report that the effect of monensin on milk fat was heterogeneous across the studies and depended on dietary factors. The relationship of monensin dose with herd milk fat percentage in the current study is depicted in Figure 3. Within this data set and the range of monensin doses represented therein, we observed no univariable relationship of monensin dose with herd milk fat percentage $(P=0.98)$. When a multivariable regression was done on all corn silage and TMR characteristics, followed by a backward step-wise elimination approach, the significant factors remaining in the model were TMR PUFA, TMR MUFA, starch content, and monensin as a categorical variable (>299 or $\leq 299 \mathrm{mg} / \mathrm{d})$. However, in the multivariable model these 4 factors together (starch content, monensin, PUFA, and MUFA) still only accounted for $32 \%$ of the variation in herd milk fat percentage in our study, indicating many variables contribute to low milk fat. These data suggest that inclusion of monensin in diets does not directly cause MFD, rather it most likely interacts with other dietary and herd-level factors when implicated in MFD.

One of the limitations of this data set is that samples were only collected from the herds on 1 occasion, and thus we are not able to examine relationships with herd-level MFD risk factors and bulk tank milk fat content over time. Although limitations exist in our data set, many herd service providers work with similar types of data when consulting with their herds on MDF challenges. Overall, univariable relationships of factors commonly thought to be associated with herd milk fat percentage (e.g., monensin dose, TMR contents of 
A

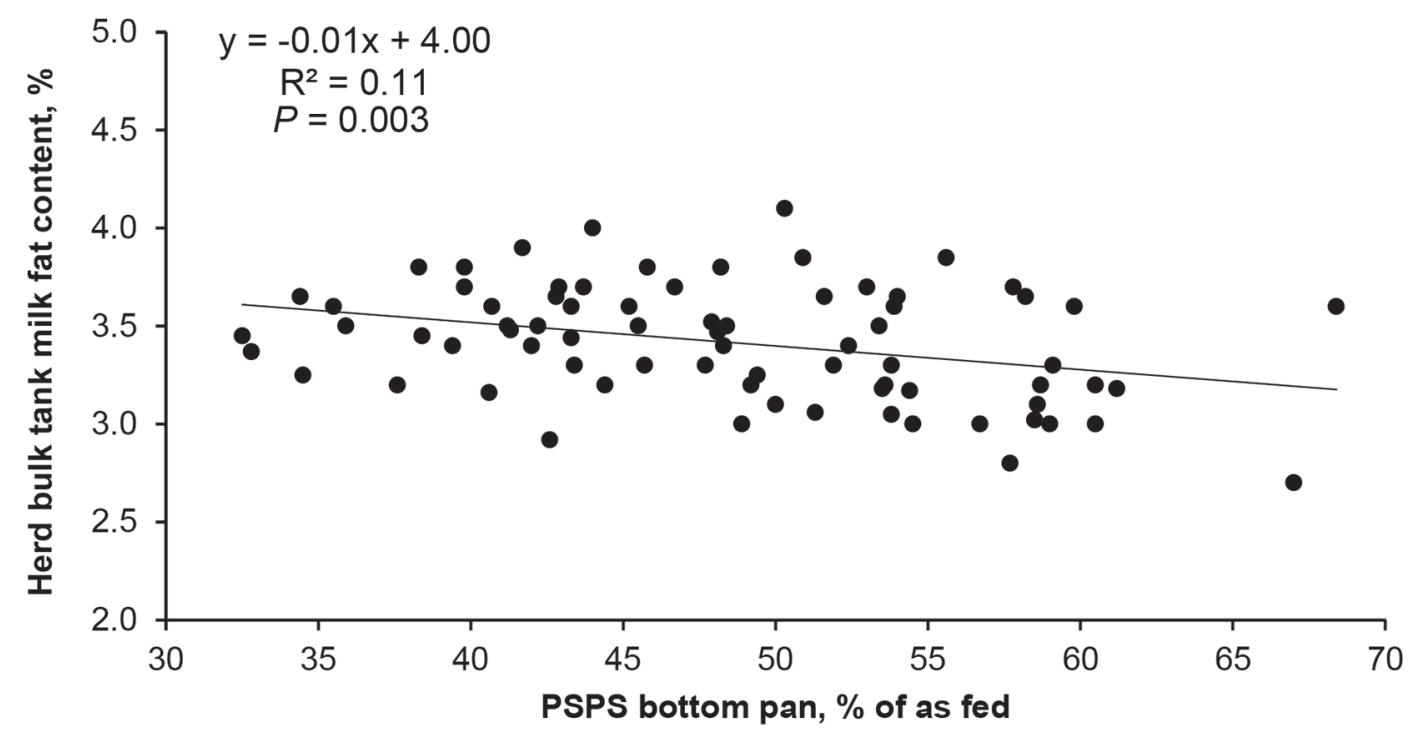

B



Figure 2. Relationship of Penn State particle separator (PSPS, Nasco, Fort Atkinson, WI) bottom pan (A) and middle screen (B) with bulk tank milk fat percentage across 79 northeast and Upper Midwest dairy herds feeding monensin.

starch, NDF, fat, and the proportion of TMR particles on the top screen of the PSPS) were not statistically significant in our study. Although increasing TMR amounts of MUFA were negatively related to herd milk fat percentage, no single TMR characteristic or diet component accounted for more than $11 \%$ of the variation in herd-level milk fat percentage. The relative lack of important univariable relationships with herd milk fat suggests that MFD is a multifactorial issue, and herds experiencing low milk fat will need to examine many potential risk factors when working to troubleshoot this challenge.

\section{ACKNOWLEDGMENTS}

The authors sincerely appreciate the collaboration of the herds and herd service providers that participated in this study along with C. M. Ryan (Cornell University) for her assistance with data collection. This work was funded by Elanco Animal Health (Greenfield, IN). 


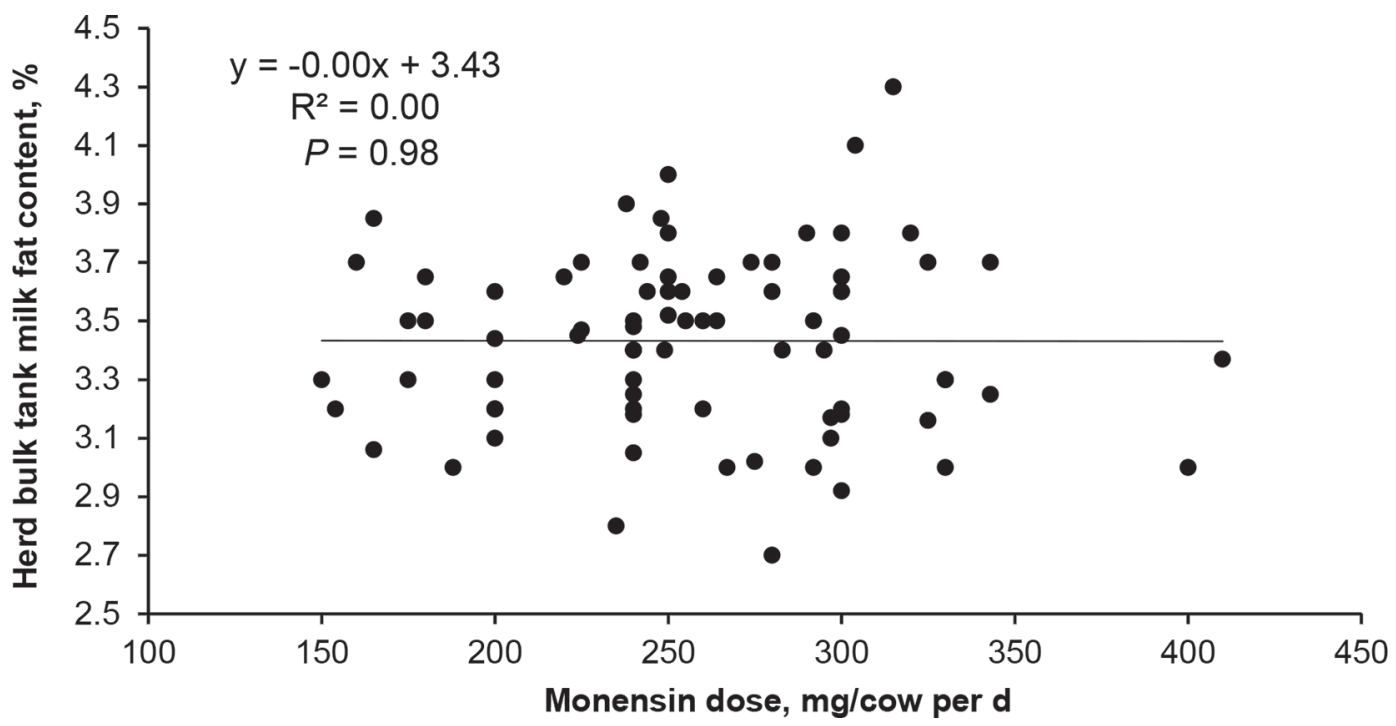

Figure 3. Relationship of monensin dose with herd milk fat percentage across 79 northeast and Upper Midwest dairy herds feeding monensin. The $P$-value for the relationship was 0.98 .

\section{REFERENCES}

AOAC International. 2000. Official Methods of Analysis. 17th ed. AOAC International, Arlington, VA.

Barbano, D. M., C. Melilli, and T. R. Overton. 2014. Advanced use of FTIR spectra of milk for feeding and health management. Pages 105-113 in Proc. Cornell Nutrition Conf. Cornell University, Ithaca, NY.

Bauman, D. E., and J. M. Griinari. 2001. Regulation and nutritional manipulation of milk fat: low-fat milk syndrome. Livest. Prod. Sci. 70:15-29.

Bauman, D. E., and J. M. Griinari. 2003. Nutritional regulation of milk fat synthesis. Annu. Rev. Nutr. 23:203-227.

Bauman, D. E., K. J. Harvatine, and A. L. Lock. 2011. Nutrigenomics, rumen-derived bioactive fatty acids, and the regulation of milk fat synthesis. Annu. Rev. Nutr. 31:299-319.

Bauman, D. E., T. Hinrichsen, C. Tyburczy, K. J. Harvatine, and A. L. Lock. 2006. Update on milk fat: Identification of rumen biohydrogenation intermediates that inhibit synthesis. Pages 59-65 in Proc. Cornell Nutrition Conf. Cornell University, Ithaca, NY.

Baumgard, L. H., B. A. Corl, D. A. Dwyer, A. Sæbø, and D. E. Bauman. 2000. Identification of the conjugated linoleic acid isomer that inhibits milk fat synthesis. Am. J. Physiol. Regul. Integr. Comp. Physiol. 278:R179-R184.

Bell, J. A., J. M. Griinari, and J. J. Kennelly. 2006. Effect of safflower oil, flaxseed oil, monensin, and vitamin $\mathrm{E}$ on concentration of conjugated linoleic acid in bovine milk fat. J. Dairy Sci. 89:733-748.

Bernal-Santos, G., J. W. Perfield II, D. M. Barbano, D. E. Bauman, and T. R. Overton. 2003. Production responses of dairy cows to dietary supplementation with conjugated linoleic acid (CLA) during the transition period and early lactation. J. Dairy Sci. 86:32183228.

Dhiman, T. R., and L. D. Satter. 1997. Yield response of dairy cows fed different proportions of alfalfa silage and corn silage. J. Dairy Sci. 80:2069-2082.

Dubois, M., K. A. Gilles, J. K. Hamilton, P. A. Rebers, and F. Smith. 1956. Colorimetric method for determination of sugars and related substances. Anal. Chem. 28:350.

Duffield, T. F., R. Bagg, D. Kelton, P. Dick, and J. Wilson. 2003 A field study of dietary interactions with monensin on milk fat percentage in lactating dairy cattle. J. Dairy Sci. 86:4161-4166.
Duffield, T. F., A. R. Rabiee, and I. J. Lean. 2008. A meta-analysis of the impact of monensin in lactating dairy cattle. Part 2. Production effects. J. Dairy Sci. 91:1347-1360.

Goering, H. K., and P. J. Van Soest. 1970. Forage Fiber Analyses (Apparatus, Reagents, Procedures, and Some Applications). Agric. Handbook. No 379. ARS-USDA, Washington, DC.

Grant, R. J., V. F. Colenbrander, and D. R. Mertens. 1990a. Milk fat depression in dairy cows: Role of particle size of alfalfa hay. J. Dairy Sci. 73:1823-1833.

Grant, R. J., V. F. Colenbrander, and D. R. Mertens. 1990b. Milk fat depression in dairy cows: Role of silage particle size. J. Dairy Sci. 73:1834-1842.

Griinari, J. M., D. A. Dwyer, M. A. McGuire, D. E. Bauman, D. L. Palmquist, and K. V. V. Nurmela. 1998. Trans-octadecenoic acids and milk fat depression in lactating cows. J. Dairy Sci. 81:12511261.

Groff, E. B., and Z. Wu. 2005. Milk production and nitrogen excretion of dairy cows fed different amounts of protein and varying proportions of alfalfa and corn silage. J. Dairy Sci. 88:3619-3632.

Hall, M. B. 2009. Analysis of starch, including maltooligosaccharides, in animal feeds: a comparison of methods and a recommended method for AOAC collaborative study. J. AOAC Int. 92:42-49.

He, M., K. L. Perfield, H. B. Green, and L. E. Armentano. 2012. Effect of dietary fat blend enriched in oleic or linoleic acid and monensin supplementation on dairy cattle performance, milk fatty acid profiles, and milk fat depression. J. Dairy Sci. 95:1447-1461.

Hinrichsen, T., A. L. Lock, and D. E. Bauman. 2006. The relationship between trans-10 18:1 and milk fat yield in cows fed high oleic acid or high linoleic acid plant oil supplements. Page 581 in Euro-Fed Lipid Congress, October 2006, Madrid, Spain.

Jenkins, T. C. 1998. Fatty acid composition of milk from Holstein cows fed oleamide or canola oil. J. Dairy Sci. 81:794-800.

Kadegowda, A. K., L. S. Piperova, and R. A. Erdman. 2008. Principal component and multivariate analysis of milk long-chain fatty acid composition during diet-induced milk fat depression. J. Dairy Sci. 91:749-759.

Krishnamoorthy, U., T. V. Muscato, C. J. Sniffen, and P. J. Van Soest. 1982. Nitrogen fractions in selected feedstuffs. J. Dairy Sci. $65: 217-225$.

Lammers, B. P., D. R. Buckmaster, and A. J. Heinrichs. 1996. A simple method for the analysis of particle sizes of forage and total mixed rations. J. Dairy Sci. 79:922-928. 
Lascano, G. J., M. Alende, L. E. Koch, and T. C. Jenkins. 2016. Changes in fermentation and biohydrogenation intermediates in continuous cultures fed low and high levels of fat with increasing rates of starch degradability. J. Dairy Sci. 99:6334-6341.

Lawton, A. B., W. S. Burhans, D. V. Nydam, M. Tetreault, and T. R. Overton. 2016. Northeast dairy herd characteristics: Transition cow management strategies, performance, culling, and health. J. Dairy Sci. 99(E-Suppl. 1):575-576.

Lock, A. L., C. Tyburczy, D. A. Dwyer, K. J. Harvatine, F. Destaillats, Z. Mouloungui, L. Candy, and D. E. Bauman. 2007. Trans-10 octadecenoic acid does not reduce milk fat synthesis in dairy cows. J. Nutr. 137:71-76.

Oba, M., and M. S. Allen. 2003. Effects of corn grain conservation method on feeding behavior and productivity of lactating dairy cows at two dietary starch levels. J. Dairy Sci. 86:174-183.

Onetti, S. G., S. M. Reynal, and R. R. Grummer. 2004. Effect of alfalfa forage preservation method and particle length on performance of dairy cows fed corn silage-based diets and tallow. J. Dairy Sci. 87:652-664.

Palmquist, D. L., A. D. Beaulieu, and D. M. Barbano. 1993. Feed and animal factors influencing milk fat composition. J. Dairy Sci. $76: 1753-1771$.

Perfield, J. W., G. Bernal-Santos, T. R. Overton, and D. E. Bauman. 2002. Effects of dietary supplementation of rumen-protected conjugated linoleic acid in dairy cows during established lactation. J. Dairy Sci. 85:2609-2617.

Ramanzin, M., L. Bailoni, S. Schiavon, and G. Bittante. 1997. Effect of monensin on milk production and efficiency of dairy cows fed two diets differing in forage to concentrate ratios. J. Dairy Sci. 80:1136-1142.

Rego, O. A., S. P. Alves, L. M. Antunes, H. J. Rosa, C. F. Alfaia, J. A. Prates, A. R. Cabrita, A. J. Fonseca, and R. J. Bessa. 2009. Ru- men biohydrogenation-derived fatty acids in milk fat from grazing dairy cows supplemented with rapeseed, sunflower, or linseed oils. J. Dairy Sci. 92:4530-4540.

Rico, D. E., and K. J. Harvatine. 2013. Induction of and recovery from milk fat depression occurs progressively in dairy cows switched between diets that differ in fiber and oil concentration. J. Dairy Sci. 96:6621-6630.

Selner, D. R., and L. H. Schultz. 1980. Effects of feeding oleic acid or hydrogenated vegetable oils to lactating cows. J. Dairy Sci. 63:1235-1241.

Sukhija, P. S., and D. L. Palmquist. 1988. Rapid method for determination of total fatty acid content and composition of feedstuffs and feces. J. Agric. Food Chem. 36:1202-1206.

Van Soest, P. J., J. B. Robertson, and B. A. Lewis. 1991. Methods for dietary fiber, neutral detergent fiber, and nonstarch polysaccharides in relation to animal nutrition. J. Dairy Sci. 74:3583-3597.

Wattiaux, M. A., and K. L. Karg. 2004. Protein level for alfalfa and corn silage-based diets: I. Lactational response and milk urea nitrogen. J. Dairy Sci. 87:3480-3491.

Woolpert, M. E., H. M. Dann, K. W. Cotanch, C. Melilli, L. E. Chase, R. J. Grant, and D. M. Barbano. 2016. Management, nutrition, and lactation performance are related to bulk tank milk de novo fatty acid concentration on northeastern US dairy farms. J. Dairy Sci. 99:8486-8497.

Woolpert, M. E., H. M. Dann, K. W. Cotanch, C. Melilli, L. E. Chase, R. J. Grant, and D. M. Barbano. 2017. Management practices, physically effective fiber, and ether extract are related to bulk tank milk de novo fatty acid concentrations on Holstein dairy farms. J. Dairy Sci. 100:5097-5106. 